\title{
ENZYMATIC DESTRUCTION OF FILM MATERIALS ON THE BASIS OF CHITOSAN IN THE PRESENCE OF CEPHALOSPORIN SERIES ANTIBIOTICS
}

\author{
Valentina Chernova ${ }^{1}$, Irina Tuktarova ${ }^{1}$, Angela Shurshina ${ }^{1}$, \\ Mariya Elinson ${ }^{1}$, Elena Kulish ${ }^{1, *}$
}

https://doi.org/10.23939/chcht13.01.071

\begin{abstract}
Enzymatic destruction of film materials on the basis of chitosan and antibiotics was analyzed. It was established that presence of drugs in a film sample caused a decrease in the rate of destruction of chitosan and led to a potentially longer service life of film material on the wound surface.
\end{abstract}

Keywords: chitosan, drug, enzymatic destruction, film materials.

\section{Introduction}

One of the promising directions in modern medicine is associated with the creation of polymeric films for a temporary protection of the skin, for example, in the treatment of burns and surgical wounds [1-3]. The most suitable polymer for this purpose is chitosan [3-7]. The film materials on the basis of chitosan have a good ability to sorption of wound discharges, are biocompatible with body tissues and bacteriostatic [8-12]. In addition, chitosan is able to process of destruction, which can be carried out under the influence of chemical and physical factors, and also under the action of biologically active environments of the human body, which eliminates an extremely painful process of changing a protective dressing [13-15]. The ability of biodestruction, for example under the influence of the enzymes which are present at a wound surface, is certainly one of the main advantages of chitosan. But, unfortunately, if this process happens quickly enough, service life of a protective wound film will not be long. In this regard, in the process of creation a film material, designed to protect the skin, it is necessary to carry out modification of chitosan, the purpose of which is to reduce the rate of enzymatic destruction of a polymer. As it was already shown, medicinal substances-antibiotics which are presented as

\footnotetext{
${ }^{1}$ Bashkir State University,

32, Zaki Validy St., 450076 Ufa, Bashkortostan

*onlyalena@mail.ru

(C) Chernova V., Tuktarova I., Shurshina A., Elinson M., Kulish E., 2019
}

low molecular weight salts can play the role of chitosan modifiers $[16,17]$. For example, it was found that the addition of antibiotics of aminoglycoside series (amikacin and gentamicin) in the amount of $0.01-0.1 \mathrm{~mol} / \mathrm{mol}$ of a polymer in the process of formation of the film caused a significant reduction in the rate of enzymatic destruction of chitosan [17]. In this work the possibility to use of antibiotics cephalosporin series - Cefazolin and Cefotaxime as chitosan modifiers is considered and their influence on the process of enzymatic destruction is studied.

\section{Experimental}

\subsection{M aterials}

In our research we used chitosan (ChT) (produced by JSC "Bioprogress", Shchelkovo, Russia) with molecular weight $M_{\eta}=113000,[\eta]=6.10 \mathrm{dl} / \mathrm{g}$ with the solvent in the acetate buffer with $4.5 \mathrm{pH}$, the degree of deacetylation $84 \%$ as well as antibiotics of cephalosporin series - Cefazolin sodium salt (CFS) and Cefotaxime sodium salt (CFT) (produced by JSC "Sintez", Russia, Fig. 1). As the enzyme preparation testicular hyaluronidase isolated from the testes of cattle was used (trade "Liraz", Microgen company, Moscow, Russia).

\subsection{Investigation Procedures}

Studying of enzymatic destruction of chitosan in the solution. To determine the values of ChT intrinsic viscosity during enzymatic destruction $[\eta]_{t}$, the solution of $\mathrm{ChT}$ in $1 \%$ acetic acid with concentration $C$ together with the enzyme preparation were mixed at $309 \mathrm{~K}$ for a certain period of time (concentration of ChT in the solution varied from 0.1 to $5 \mathrm{~g} / \mathrm{dl}$, time - from 10 to $180 \mathrm{~min})$. Concentration of the enzyme preparation in all experiments was $0.1 \mathrm{~g} / \mathrm{l}$. After that, the process was stopped by boiling the initial solution for $30 \mathrm{~min}$ in a water bath. Then solution for determination of intrinsic viscosity with concentration $C=0.15 \mathrm{~g} / \mathrm{dl}$ was prepared by dilution of the solution with the initial concentration $C$. 


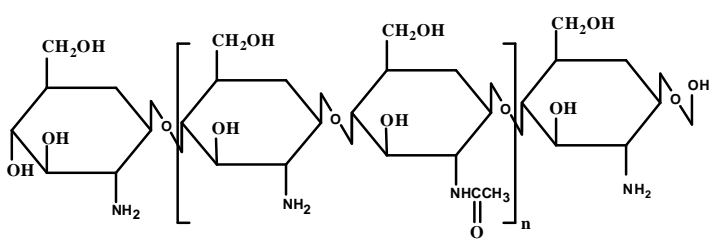

a)

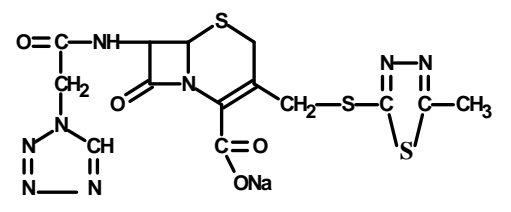

b)

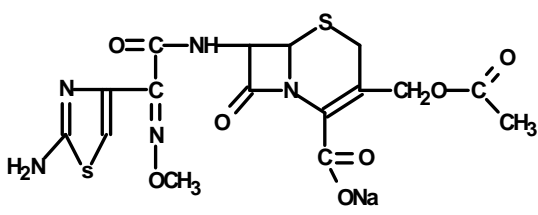

c)

Fig. 1. Structure of the investigated substances: chitosan (a); Cefazolin (b) and Cefotaxime (c)

Definition of intrinsic viscosity. Intrinsic viscosity of ChT $[\eta]$ in solution of acetic acid was determined by Baranov's method according to the tangent of the slope at the initial part of the curve $\ln \eta_{r}-C$ (Fig. 2), where $\eta_{r}-$ relative viscosity [18]. The solution with concentration $C=0.15 \mathrm{~g} / \mathrm{dl}$ was used to determine the values of initial intrinsic viscosity $\mathrm{ChT}[\eta]_{0}$.

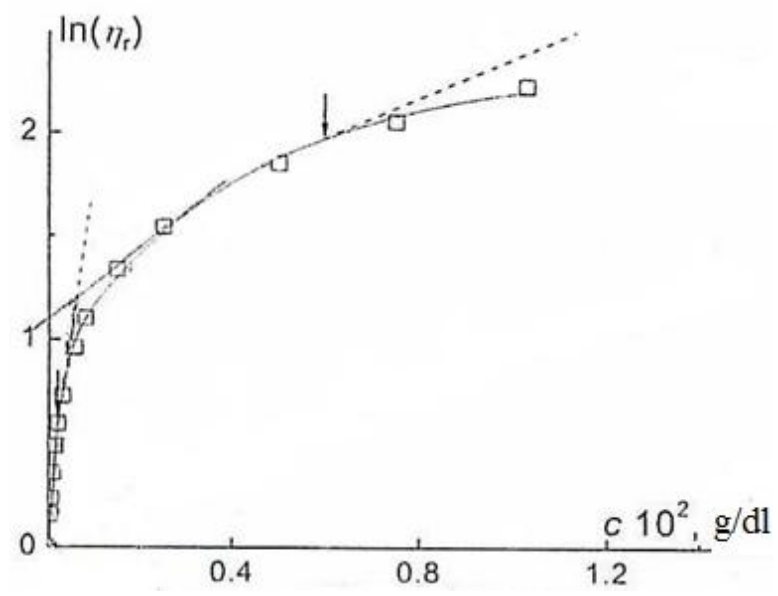

Fig. 2. Dependence of $\ln \eta_{r}$ on $C$ of the sample.

The slopes of the tangents to the dependence of $l n \eta_{r}$ on $C$ correspond to the values of "current intrinsic viscosity"

Determination of initial rate of enzymatic destruction. The value of the initial rate of enzymatic destruction $V_{0}$ was calculated by the formula:

$$
V_{0}=C \cdot K^{1 / \alpha} \cdot \frac{[\eta]_{\tau}^{-1 / \alpha}-[\eta]_{0}^{-1 / \alpha}}{t}
$$

where $C$ is the concentration of ChT exposed to process of enzymatic destruction in the solution, $\mathrm{g} / \mathrm{dl} ; t$ is time of hydrolysis, min; $K$ and $\alpha$ are constants in the equation of Mark-Kuhn-Houwink determined according to the methodology [19].
In case of carrying out destruction of film samples the concentration of ChT which is exposed to process of enzymatic destruction was designated as $c_{s}-$ a surface concentration of ChT links which are available for interaction with the enzyme preparation.

Preparation of polymeric films. For preparation of a film of initial ChT the sample of polymer $(0.8 \mathrm{~g})$ was dissolved in $40 \mathrm{ml}$ of $1 \%$ acetic acid (2\% solution of polymer). Full dissolution of polymer happened within 2 days at hashing. Films were formed by a watering method on a glass surface (Petri dish).

To prepare ChT-CFS and ChT-CFT films, ChT solution $(0.8 \mathrm{~g}$ in $40 \mathrm{ml}$ of $1 \%$ acetic acid) was added to aqueous solution of CFS or CFT ( $2 \mathrm{ml})$ with a molar ratio $\mathrm{LV}: \mathrm{ChT}=0.01: 1,0.05: 1$ or $0.1: 1$ at hashing. Hashing was carried out within $15 \mathrm{~min}$. Films were formed by a watering method on a glass surface (Petri dish).

Definition of superficial concentration of units. The following ideas were used for determination of the surface concentration of $c_{s}$ units $(\mathrm{g} / \mathrm{dl})$ in the volume of enzyme solution. If we know mass of a film sample $m_{f}$, we can calculate the number of monomer units of $\mathrm{ChT} n_{v}$ for the whole volume of the film:

$$
n_{v}=m_{f} \cdot \frac{N_{A}}{M_{u}}
$$

where $M_{u}$ - the molecular weight of ChT unit; $N_{A}-$ Avogadro number.

Further we assume that a monomer unit of ChT is inscribed in a cube with $d$ edge. Then the volume occupied by the monomer unit in the film amount is equal to:

$$
V_{u}=\frac{V_{f}}{n_{v}}
$$

where $V_{f}$ is the volume of the film sample. Hence, the size of the side $d=\left(V_{u}\right)^{1 / 3}$.

Now it is possible to estimate a number of monomeric units $n_{u}$ on a film surface with a total area of 
$S_{f}$; the surface contacts with the solution of enzyme preparation. It should be mentioned that each monomeric unit occupies space $S_{u}=d^{2}$.

$$
n_{u}=\frac{S_{f}}{S_{u}}
$$

The exact area of a film sample, which is necessary for calculation of $c_{s}$ was determined on the data basis of an electronic scanning microscopy $[20,21]$.

Studying of enzymatic destruction of film samples. Some patterns were cut out from film samples with certain linear size for studying the process of enzymatic destruction. The film thickness was equal to $100 \mu \mathrm{m}$.

The film sample of ChT was placed on the substrate, moistened with the solution of enzyme preparation in $1 \%$ acetic acid and kept for a certain time at the constant temperature $(309 \mathrm{~K})$ for carrying out the experiment, modeling the process of enzymatic destruction of ChT on the wound surface. The volume of the solution of enzyme preparation $(0.1 \mathrm{ml})$ was chosen in such a case that the entire film surface was covered with the enzyme solution. The amount of enzyme contacting with the film was equal to its quantity when conducting degradation in the solution. After aging, the process of enzymatic destruction was stopped by enzyme deactivation in the process of boiling for $30 \mathrm{~min}$ in a water bath. Next, the film was dissolved in $1 \%$ acetic acid to determine the current value of the intrinsic viscosity of the polymer $[\eta]_{t}$.

Definition of glycosidase activity. Glycosidase activity of the enzyme preparation was determined by ferricyanide method, which consisted of determining the concentration of regenerative sugars [22].

\section{Results and Discussion}

\subsection{Study of Enzymatic Destruction of Chitosan Solution}

Previously [23, 24] it was shown that exposure of ChT solution in the presence of the enzyme was accompanied by a gradual decrease in the values of its intrinsic viscosity, indicating the decrease of a molecular weight of the polymer as a result of the process of enzymatic destruction (Fig. 3, curve 1). The change in ChT intrinsic viscosity in the presence of CFS and CFT has a similar character (Fig. 3, curves 2-3): in case of a little time of destruction, curves of changes of viscosity in time have got a linear character, similar to how it was shown in the system of ChT-antibiotic of aminoglycoside series [16], further the rate of process decreases. This course of a kinetic curve is typical for most enzymatic reactions [23]. The value of the initial rate of enzymatic destruction $V_{0}$ was determined in the initial linear range.

According to the studies, the observed dependence of the initial rate of enzymatic destruction of ChT in the presence of CFZ and CFT on concentration of the substrate (ChT) (Fig. 4) can be described in terms of Michaelis-Menten, as well as in case of enzymatic destruction of ChT in the absence of the drug [24]. The values of Michaelis's constant defined graphically by method of Leinweber Berka are presented in Table 1.

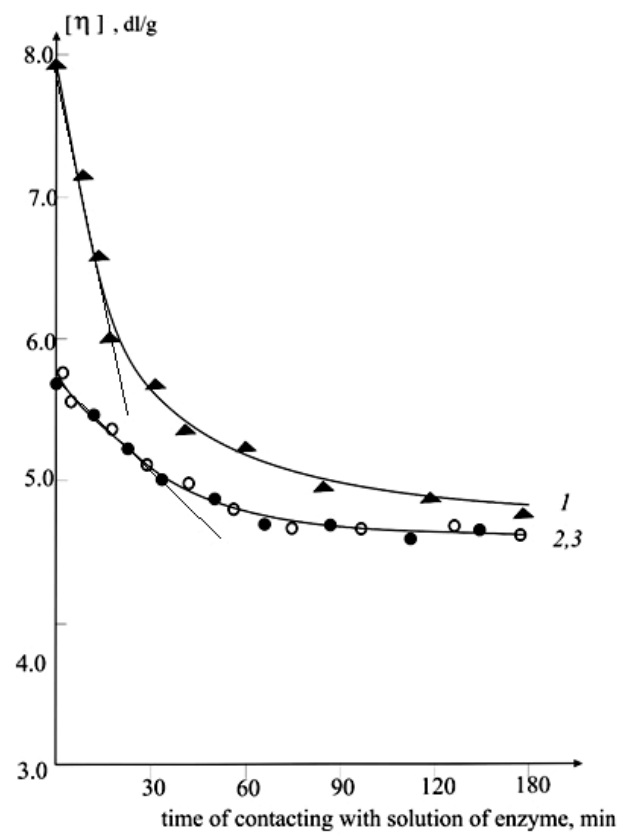

Fig. 3. The dependence of ChT intrinsic viscosity in the absence (1) and presence of CFS (2) and CFT (3) in the amount of $0.01 \mathrm{~mol} / \mathrm{mol} \mathrm{ChT}$ on the time of contacting with a solution of enzyme preparation

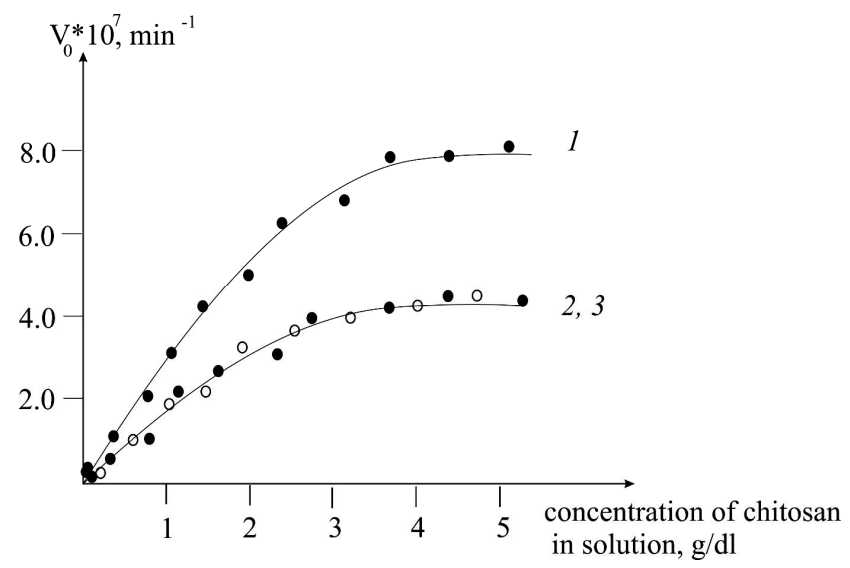

Fig. 4. The dependence of the initial rate of enzymatic destruction of ChT (1), ChT-CFS (2) and ChT-CFT (3) on ChT concentration in the solution. The content of CFS and CFT is $0.1 \mathrm{~mol} / \mathrm{mol} \mathrm{ChT}$ 
The values of constants in the Michaelis-Menten equation for the systems of ChT-CFS and ChT-CFT in $1 \%$ acetic acid

\begin{tabular}{|c|c|c|c|c|}
\hline Research system & Molar ratio of the components ChT: antibiotic & $K_{m}, \mathrm{~g} / \mathrm{dl}$ & $V_{\max } \cdot 10^{6}, \mathrm{~min}^{-1}$ & $\left(V_{\max } / K_{m}\right) \cdot 10^{6}, \mathrm{~g} / \mathrm{dl} \cdot \mathrm{min}$ \\
\hline ChT & $1: 0$ & 3.37 & 0.50 & 0.15 \\
\hline \multirow{3}{*}{ ChT-CFS } & $1: 0.01$ & 3.80 & 0.48 & 0.13 \\
\cline { 2 - 5 } & $1: 0.05$ & 3.86 & 0.42 & 0.11 \\
\cline { 2 - 5 } & $1: 0.10$ & 3.92 & 0.36 & 0.09 \\
\cline { 2 - 5 } ChT-CFT & $1: 0.01$ & 3.77 & 0.50 & 0.13 \\
\cline { 2 - 5 } & $1: 0.05$ & 3.84 & 0.45 & 0.12 \\
\cline { 2 - 5 } & $1: 0.10$ & 3.89 & 0.38 & 0.10 \\
\hline
\end{tabular}

Table 2

The values of constants $\alpha$ and $K$ in Mark-Kuhn-Houwink's equation and an intrinsic viscosity of chitosan

\begin{tabular}{|c|c|c|c|c|}
\hline Research system & Molar ratio of the components ChT: antibiotic & $\alpha$ & $K \cdot 10^{4}$ & {$[\eta]$} \\
\hline ChT & $1: 0$ & 1.02 & 0.56 & 7.80 \\
\hline \multirow{3}{*}{ ChT-CFS } & $1: 0.01$ & 0.93 & 1.53 & 7.50 \\
\cline { 2 - 5 } & $1: 0.05$ & 0.92 & 1.61 & 6.24 \\
\cline { 2 - 5 } & $1: 0.10$ & 0.90 & 1.68 & 5.67 \\
\hline \multirow{3}{*}{ ChT-CFT } & $1: 0.01$ & 0.94 & 1.50 & 7.47 \\
\cline { 2 - 5 } & $1: 0.05$ & 0.93 & 1.59 & 6.13 \\
\cline { 2 - 5 } & $1: 0.10$ & 0.91 & 1.66 & 5.72 \\
\hline
\end{tabular}

Table 3

The values of enzymatic destruction rate of ChT, ChT-CFS and ChT-CFT films

\begin{tabular}{|c|c|c|c|c|}
\hline Research system & Molar ratio of the components ChT: antibiotic & $\begin{array}{c}\mathrm{c}_{\mathrm{s}} \cdot 10^{4}, \\
\mathrm{~g} / \mathrm{dl}\end{array}$ & $\begin{array}{c}V_{0} \cdot 10^{11}, \\
\min ^{-1}\end{array}$ & $\begin{array}{c}V_{0}^{5} \cdot 10^{11}, \\
\min ^{-1}\end{array}$ \\
\hline \multirow{3}{*}{ ChT } & \multirow{3}{*}{ 1:0 } & 1.62 & 2.36 & 2.40 \\
\hline & & 1.96 & 2.86 & 2.90 \\
\hline & & 2.33 & 3.47 & 3.50 \\
\hline \multirow{9}{*}{ ChT-CFS } & \multirow{3}{*}{ 1:0.01 } & 1.67 & 2.19 & 2.17 \\
\hline & & 2.06 & 2.66 & 2.68 \\
\hline & & 2.40 & 3.10 & 3.12 \\
\hline & \multirow{3}{*}{$1: 0.05$} & 1.72 & 1.91 & 1.89 \\
\hline & & 2.06 & 2.24 & 2.27 \\
\hline & & 2.48 & 2.76 & 2.73 \\
\hline & \multirow{3}{*}{$1: 0.10$} & 1.70 & 1.51 & 1.53 \\
\hline & & 2.11 & 1.92 & 1.90 \\
\hline & & 2.47 & 2.19 & 2.22 \\
\hline \multirow{9}{*}{ ChT-CFT } & \multirow{3}{*}{$1: 0.01$} & 1.66 & 2.14 & 2.16 \\
\hline & & 2.05 & 2.69 & 2.66 \\
\hline & & 2.41 & 3.11 & 3.13 \\
\hline & \multirow{3}{*}{ 1:0.05 } & 1.74 & 2.08 & 2.09 \\
\hline & & 2.04 & 2.48 & 2.45 \\
\hline & & 2.46 & 2.93 & 2.95 \\
\hline & \multirow{3}{*}{$1: 0.10$} & 1.71 & 1.74 & 1.71 \\
\hline & & 2.13 & 2.10 & 2.13 \\
\hline & & 2.46 & 2.44 & 2.46 \\
\hline
\end{tabular}

Note: $V_{0}^{5}$ - the value of the initial rate of enzymatic hydrolysis is calculated according to Eq. (5) 
Due to the fact that the addition of CFS and CFT to the solution of enzyme preparation does not reduce its glycosidase activity (the value of hyaluronidase activity in the absence and the presence of antibiotics is $70 \mathrm{E} / \mathrm{g}$ ), the only reason for decreasing the rate of enzymatic destruction of ChT, from our point of view, is the change in a conformational state of the polymer in the solution in the presence of CFS and CFT. Such a change takes place according to the values of the constants of Mark-KuhnHouwink defined for ChT in the absence and the presence of CFS and CFT (Table 2). It is also proved by the decrease in intrinsic viscosity of the initial ChT when adding antibiotics (not subjected to the process of enzymatic destruction). A similar effect of CFS and CFT can be explained if you consider the fact that these antibiotics represent low molecular weight electrolytes. Being in ChT solution and representing polycation, they cause an increase in ionic strength of the solution and the suppression of polyelectrolyte swelling effect.

Thus, reduced size of a macromolecular coil and, consequently, some increase in the density lead to the changes in the availability of ChT units for interaction with the enzyme preparation, resulting in the decrease in the rate of enzymatic destruction.

It is important that regularities of CFS and CFT influence the rate of enzymatic destruction of ChT in the solution are preserved during transition to film samples.

\subsection{Study of Enzymatic Destruction of Film Samples on the Basis of Chitosan}

By varying the geometry of film samples of chitosan films, we obtained samples with different surface concentration of ChT $c_{s}$ units. Then, we carried out a process of destruction of films, determined changes in the values of intrinsic viscosity and calculated values of rate $V_{0}$ of enzymatic destruction of film samples according to Eq. (1) (Table 3).

But $V_{0}$ value can be calculated in another way, using the value of $V_{\max } / K_{m}$ during enzymatic destruction in the solution. In this case, $V_{0}$ value at the initial (linear) plot of the rate dependence of enzymatic hydrolysis on concentrations of substrate (ChT), i.e. at low concentrations of the substrate corresponding to the area of concentration, which characterizes the film samples, can be calculated as:

$$
V_{0}=\frac{V_{\max }}{K_{m}} \cdot c_{s}
$$

Table 3 shows the values of the initial rate of enzymatic hydrolysis of $V_{0}$ film samples defined by the Eqs. (1) and (5). They are in good correspondence with each other. This fact suggests that enzymatic destruction of ChT-CFS and ChT-CFT drug films is governed by the same kinetic laws as the destruction of a polymer in the solution and is satisfactorily described in the framework of Michaelis-Menten's mechanism. Fundamentally important is the fact that the introduction of the protective film material on the basis of ChT-cephalosporin antibiotics leads to a significant reduction in the rate of enzymatic destruction of films, which should result in a longer service life of such material on the wound surface.

\section{Conclusions}

Thus, the study of kinetic peculiarities of the process of enzymatic hydrolysis of chitosan in the presence of drugs of cephalosporin series antibiotics under the action of nonspecific enzyme hyaluronidase on the wound surface of the human body is characterized by $\beta$ glycoside activity in chitosan. It also revealed some general physico-chemical (kinetic) patterns.

1. Polyelectrolyte nature of chitosan leads to the fact that the increase in ionic strength of the solution is achieved by addition of drug compounds which affects the conformational state of the macromolecules of chitosan, namely, reducing the size of the equilibrium coils and increases the packing density of the links. This is characterized by the decrease in the values of intrinsic viscosity of chitosan solutions and constants in the equation of Mark-Kuhn-Houwink defined in the presence of drug compounds. It is important that the change in the conformational state of ChT caused by the presence of drugs, has a crucial influence on the kinetic process of the enzymatic hydrolysis of chitosan, because it reduces the availability of chitosan units to interact with the enzyme.

2. It is established that enzymatic hydrolysis of chitosan under the action of hyaluronidase can be described in the framework of Michaelis-Menten's mechanism. The change in the kinetic parameters of the process caused by the presence of medicinal compoundsantibiotics in all investigated cases resulted in $V_{\max }$ decrease and in $K_{m}$ increase and it also led to $V_{\max } / K_{m}$ decrease, which is characterized by the physical meaning of a reaction rate constant. The increase of $K_{m}$ indicates a deterioration of the affinity between enzyme and substrate apparently caused by the contraction of the macromolecular ball. It should be noted that the decrease of the rate of the enzymatic hydrolysis occurs on the background of the fact that the selected compounds do not affect a total activity of hyaluronidase.

3. The developed approach to the study of enzymatic hydrolysis of chitosan film samples in mixtures with drugs-antibiotics, which are low molecular weight organic salts, with surface concentration units of chitosan revealed the identity of the kinetic parameters of the enzymatic hydrolysis of chitosan films and parameters of 
the hydrolysis of similar systems in the solution at low concentrations of substrate. This fact allows to obtain reliable results on the kinetic parameters of the process of biodegradation of polymeric material by analyzing only the process of enzymatic hydrolysis of the films without the study of the process of enzymatic hydrolysis in the solution.

Thus, it can be proved that the introduction of drug compounds into the film material on the basis of CHTZ causes the suppression of the effect of polyelectrolyte swelling. A corresponding decrease in availability of CHTZ links for interaction with the enzyme may be considered as a method aimed at a speed reduction of HCTZ enzymatic hydrolysis with the purpose of the potential increase in service life of the film material on the wound surface.

\section{Acknowledgements}

The work is performed with financial support of the Ministry of Education and Science of the Russian Federation within a basic unit of the state task in the sphere of scientific activity the project No. $4.5032 .2017 / \mathrm{BCh}$

\section{References}

[1] Upadhyay G., Verma S., Parvez N., Sharma P.: Adv. Biolog. Res., 2014, 8, 131. https://doi.org/10.5829/idosi.abr.2014.8.3.8446 [2] Boateng J., Matthews K., Stevens H., Eccleston G.: J. Pharmaceut. Sci., 2008, 97, 2892. https://doi.org/10.1002/jps.21210 [3] Morris G., Kok S., Harding S., Adam G.: Biotechnol. Genet. Eng. Rev., 2010, 27, 257. https://doi.org/10.1080/02648725.2010.10648153

[4] Alekseeva T., Rahmetova O., Bogoslovskaja A. et al.: Izvestija Ros. Acad. Nauk, 2010, 4, 403.

[5] Muzarelli R.: Chitin. Pergamon Press, Oxford 1977. [6] Bol'shakov I., Gorbunov N., Shamova N. et al.: Pat. RU 2254145, Publ. June 20, 2005.

[7] Lim C-H., Hudson S.: J. Macromol. Sci., 2003, 43, 223. https://doi.org/10.1081/MC-120020161

[8] Liu H., Du Y., Wang X., Sun L.: Int. J. Food Microbiol., 2004, 95, 147. https://doi.org/10.1016/j.ijfoodmicro.2004.01.022 [9] Liu X. et al.: J. Appl. Polym. Sci., 2001, 79, 1324. https://doi.org/10.1002/1097-4628(20010214)79:7<1324::AIDAPP210>3.0.CO;2-L
[10] Moon J.-S. et al.: Appl. Microbiol. Biotechnol. 2007, 75, 989. https://doi.org/10.1007/s00253-007-0898-8

[11] Kong M. et al.: Int. J. Food Microbiol., 2010, 144, 51. https://doi.org/10.1016/j.ijfoodmicro.2010.09.012

[12] Buzinova D., Shipovskaja A.: Izv. Saratov. Univ., 2008, 8, 42.

[13] Kulish E., Chernova V., Volodina V., Kolesov S.: Plast. Massy, $2008,8,42$.

[14] Il'ina A., Varlamov V.: Prikl. Biokhim. Mikrobiolog., 2003, 39, 237.

[15] Chernova V.: PhD thesis, Bashkir State University, Ufa 2011.

[16] Kulish E., Tuktarova I., Chernova V.: Perspektiv. Mater., 2014, $6,25$.

[17] Chernova V., Tuktarova I., Kulish E.: Appl. Biochem.

Microbiol., 2016, 52, 525.

https://doi.org/10.1134/S0003683816050057

[18] Baranov V., Brestkin Ju., Agranova S., Pinkevich V.:

Vysokomol. Soed., 1986, 28B, 841.

[19] Tuktarova I., Chernova V., Lazdin R., Kulish E.: Fizikokhim. Poverhnosti i Zashhita Mater., 2016, 10, 203.

[20] Kulish E., Shurshina A., Kolesov S.: Rus. J. Appl. Chem., 2013, 10, 1537. https://doi.org/10.1134/S107042721310011X

[21] Kulish E., Shurshina A., Kolesov S.: Polym. Sci. A., 2014, 56, 289. https://doi.org/10.1134/S0965545X14030080

[22] Severin S.: Praktikum po Biokhimii. Izd-vo MGU, Moskva 1989.

[23] Kulish E., Chernova V., VolodinaV. et al.: Vestnik Bashkir. Univ., 2008, 13, 259.

[24] Kulish E., Tuktarova I., Chernova V., Kolesov S.: Vestnik Bashkir. Univ., 2013, 18, 688.

Received: September 04, 2017 / Revised: October 22, 2017 / Accepted: February 27, 2018

\section{ФЕРМЕНТАТИВНА ДЕСТРУКЦІЯ ПЛІВКОВИХ МАТЕРІАЛІВ НА ОСНОВІ ХІТОЗАНУ В ПРИСУТНОСТІ АНТИБІОТИКІВ ЦЕФАЛОСПОРИНОВОГО РЯДУ}

Анотація. Досліджено ферментативну деструкцію лікарських плівкових матеріалів на основі хітозану та антибіотиків церфалоспоринового ряду. Встановлено, щуо наявність церазоліну $i$ цефатоксиму у плівкових зразках зменшує швидкість деструкиї хітозану $і$ приводить до потениійно довшого терміну служби захисного плівкового матеріалу на рановій поверхні.

Ключові слова: хітохан, лікарський препарат, ферментативна деструкиія, плівкові матеріали. 